\title{
Reviewing The Handling Of Covid-19 In Indonesia In The Perspective Of The Pancasila Element Theory (TEP)
}

\author{
I Gusti Ngurah Santika ${ }^{1)}$, I Made Kartika ${ }^{2)}$, I Gusti Ayu Mas Darwati ${ }^{3)}$ \\ Elementary School Teacher Education Study Programme, Faculty of Teacher Training and Education, \\ Universitas Dwijendra, Jl. Kamboja No.17, Denpasar, Indonesia 80113 1) \\ Pancasila and Citizenship Education Study Program, Faculty of Teacher Training and Education, \\ Universitas Dwijendra, Kamboja Street No. 17, Denpasar Indonesia $80113^{\text {2,3) }}$ \\ ngurahsantika88@gmail.com
}

\begin{abstract}
The purpose of this research was to review the handling of Covid-19 in Indonesia using the Pancasila Element Theory (TEP). The method used in this research was descriptive qualitative. Data collection methods used in this research were documentation and literature studies. Based on the Pancasila Element Theory, the handling of Covid-19 in Indonesia can be viewed from the problems, thoughts, ideas, acceptance, agreement, truth, and peace. The results of this research indicated that Covid-19 with its characteristics was a problem that encourages the emergence of thoughts from competent people. From that thought, various ideas were born in the form of appeals and regulations issued by the Government. However, citizen acceptance of the Government's efforts to prevent the spread of Covid-19 in Indonesia was very low. This happened because of a disagreement between the Government and its citizens in viewing Covid-19. If so, it is impossible for the handling of Covid-19 in Indonesia to be done properly. This means that the handling of Covid-19 in Indonesia contains problems, so it is impossible to achieve peace.
\end{abstract}

Keywords: Handling Covid-19; Pancasila Element Theory; TEP

\begin{abstract}
Abstrak. Tujuan penelitian ini untuk meninjau penanganan Covid-19 di Indonesia dengan menggunakan Teori Elemen Pancasila (TEP). Metode yang digunakan dalam penelitian ini adalah deskriptif kualitatif. Metode pengumpulan data yang digunakan dalam penelitian ini adalah studi dokumentasi dan literature. Berdasarkan Teori Elemen Pancasila penanganan Covid-19 di Indonesia dapat ditinjau dari permasalahan, pemikiran, gagasan, penerimaan, kesepakatan, kebenaran, dan kedamaian. Hasil penelitian ini menunjukan, bahwa Covid-19 dengan karakteristiknya merupakan permasalahan yang mendorong munculnya pemikiran dari orang-orang kompeten. Dari pemikiran itu, lahirlah berbagai gagasan dalam bentuk himbauan dan aturan yang dikeluarkan Pemerintah. Tetapi rendah sekali penerimaan warga terhadap usaha Pemerintah dalam mencegah penyebaran Covid-19 di Indonesia. Hal itu terjadi karena adanya ketidaksepakatan antara Pemerintah dengan warganya dalam memandang Covid-19. Kalau begitu tidak mungkin penanganan Covid-19 di Indonesia bisa dilakukan dengan benar. Berarti penanganan Covid-19 di Indonesia mengandung permasalahan, sehingga tidak mungkin tercapai kedamaian.
\end{abstract}

Kata Kunci: Penangan Covid-19; Teori Elemen Pancasila;TEP 


\section{INTRODUCTION}

Since it first appeared in Wuhan City, China, Covid-19 has always been a hot topic that has captured the world's attention. Its figure is still mysterious, making Covid 19 one of the most interesting viruses gossiped about by the international community (Lin et al., 2020). Meanwhile, from time to time the accumulative number of people exposed to Covid-19 around the world continues to increase sharply (WHO, 2020).

The increase in Covid-19 cases in general is not only happening globally. Indonesia as a country exposed to Covid-19 also shows similar symptoms. Reflecting on the data from the Covid-19 Handling Task Force, until now the number of residents confirmed to have been exposed to Covid-19 in Indonesia has reached 869,600 people with details of 711,205 recovered and 25,246 died (Covid Handling Task Force, 2021).

In fact, the Government has taken a number of steps, both preventive and repressive in nature. This step was set forth by the Government in the form of recommendations and policies (Santika, 2021a). The ultimate goal is to break the chain of Covid-19 transmission in Indonesia. Government appeal, for example in the form of physical distancing recommendations, use of masks, wash hands, use hand sanitizers, stay at home, and adopt a healthy lifestyle.

In addition, the Government has also made policies to prevent the spread of Covid-
19, such as Large-Scale Social Restrictions regulated in Government Regulation (PP) No. 21 of 2020, Presidential Decree No. 11 of 2020 concerning the Determination of Covid-19 Public Health Emergencies, Presidential Decree No. 12 of 2020 concerning the Determination of the National Disaster for the Spread of Corona Virus Disease (Covid-19) as a National Disaster, Regulation of the Minister of Health No. 9 of 2020 concerning PSBB Guidelines for the Acceleration of Handling Covid-19. Circular No. 57 of 2020 concerning the Extension of Work From Home (WFH) for State Civil Servants (ASN), and others.

It is interesting to know why the Government's efforts to control the spread of Covid-19 have not shown success. Because until now the Government's efforts have not shown any signs that Indonesia will soon come out of the Covid-19 crisis. So to understand this phenomenon, researchers tried to use the Pancasila Element Theory. The Pancasila Element Theory consists of problems, thoughts, ideas, acceptance, agreement, truth, and peace. Based on the Pancasila Element Theory, it will be known why the Government's efforts to prevent the spread of Covid-19 have not been achieved so far.

\section{RESEARCH METHODS}

The method used in this research was descriptive qualitative. Qualitative descriptive research seeks to describe a social phenomenon that is focused on solving 
problems in the present and future. The social symptom or phenomenon referred to in this study is the spread of Covid-19 in Indonesia. Then the handling of Covid-19 was reviewed from the perspective of the Pancasila Element Theory. Data collection methods used were documentation and literature studies. The literature study carried out, namely by searching for various written sources, both in the form of books, archives, magazines, articles and journals as well as documents that can assist researchers in reviewing the handling of Covid-19 in Indonesia from the perspective of the Pancasila Element Theory ( TEP).

\section{DISCUSSION}

To review the handling of Covid-19 in Indonesia, it will be carried out using the Pancasila Element Theory adopted from the Contextual Exploring and Finding the Spirit of Pancasila (Santika, 2020). The Pancasila Element Theory consists of problems, thoughts, ideas, acceptance, agreement, truth, and peace.

\section{Problems.}

Viewed from the perspective of the Pancasila Element Theory, the problem in this case is Covid-19. Since its appearance in Wuhan City, China at the end of December 2019 (Liu et al., 2020), Covid-19 is a difficult problem for humans. Because Covid-19 is not only endemic in China, but has become a global pandemic. The main problem with Covid-19 is its contagious characteristics. Covid-19 infects very quickly from one human body to another (Santika, 2020). Covid-19 is also a virus that is quite deadly. Just look at data published by the World Health Organization (WHO) on January 20, 2021, that confirmed cases of Covid-19 were 94,124,612 with deaths reaching 2,034,527 (WHO, 2021).

By looking at the development of Covid-19 in the world, a complete picture is obtained, that Indonesia is also facing the same problems (Nasruddin \& Haq, 2020). Because since it was first officially announced by the Government on March 2, 2020 (Agustino, 2020), until now the Covid-19 cases have soared. Based on data obtained from the Covid-19 Handling Task Force, that residents who were exposed to Covid-19 until January 20, 2021 reached 927,380 with details of 753,948 recovered and 26.590 died (Covid Handling Task Force, 2021).

Accumulatively, so many people have been infected with Covid-19, showing how terrible this virus is for humans. In general, Covid-19 as a problem is more of its consequences in various fields of life.

\section{Thoughts.}

In the perspective of the Pancasila Element Theory, thoughts emerge because of human desire to solve their life problems. If analyzed critically, the emergence of Covid-19 is a serious problem that must be resolved. In 
the context of thinking, it is relevant to discuss who thinks and what he thinks in order to solve the Covid-19 issue.

How to break the chain of spreading Covid-19 in Indonesia is a method. Finding the right method to prevent the spread of Covid-19 certainly requires logical thinking. Because it must be realized that problems that have arisen due to Covid-19 can only be resolved properly if they are based on logical, critical, and analytical thinking. So touching on methods to control the spread of Covid-19 is more about what you think. Meanwhile, who thinks of a method to control the spread of Covid-19 is to focus on people who have competence or authorized institutions.

The person in question is having the ability to help the Government in preventing the spread of Covid-19. Such as the thoughts of various higher education academics in Indonesia through their research. Of course, the thinking of an academic has gone through a scientific method that can be tested for validity (Santika, 2017). In addition, what is no less important is the thoughts contributed by medical personnel. Given that medical personnel (both doctors and nurses) are people who are at the forefront of fighting Covid-19.

In addition, the thoughts of people sitting in state institutions. Their thinking is decisive (Santika, 2021b). Because these state institutions do have a duty to control the transmission of Covid-19. The state institution that handles Covid-19 in Indonesia is the
Government. Within the government structure, a special department was formed to take care of the health of the Indonesian people. That department is the Ministry of Health. Even in the context of accelerating the response to Covid-19 in Indonesia, the Government has formed a Task Force for the Acceleration of Handling Corona Virus Disease 2019 (Covid19). Among the thoughts that exist the thoughts of people in Government are the most fundamental of other thoughts. Because that person's thoughts represent the will of the state officially.

\section{Ideas}

In the perspective of the Pancasila Element Theory, an idea is an action that is born from the results of thinking to unravel the problem. In this context, the idea in question refers more to the efforts made to tackle the spread of Covid 19. For example, according to research, Covid-19 can be transmitted to other people. Transmission can be through the splashes that come out of the mouths of people infected with Covid-19 (Siahaineinia \& Bakara, 2020) The government also urges its citizens to always wear masks when leaving the house. The government also encourages its citizens to wash their hands frequently with soap. Not only an appeal, the Ministry of Health through the Director General of Public Health issued a Circular No. HK 02.02 / I / 385/2020 concerning the Use of Masks and Provision of Handwashing Facilities with 
Soap (CTPS) to Prevent the Transmission of Corona Virus Desease 19 (Covid-19).

Apart from that, the Government has also taken steps to prevent the spread of Covid19 by encouraging residents not to crowd. On several occasions the Government has emphasized that maintaining distance is no longer just an appeal, but must be interpreted as an imperative command. Moreover, the National Police Chief has issued a Declaration by the Head of the National Police of the Republic of Indonesia Number: Mak/2/III/2020 concerning Compliance with Government Policies in Handling the Spread of the Corona Virus (Covid-19) (Faisal et al., 2020).

To prevent the spread of Covid-19, the Government through its authority has issued Government Regulation (PP) No. 21 of 2020 concerning Large-Scale Social Restrictions in the Context of Accelerating the Handling of Corona Virus Desease 19 (Covid-19) (Rahmatullah, 2020). Not to be left behind, the Minister of Health also issued a Minister of Health Regulation No.9 of 2020 concerning Guidelines for Large-Scale Social Restrictions in the Context of Accelerating the Handling of Corona Virus Disease 2019 (Covid-19).

In an effort to accelerate the handling of Covid-19 in Indonesia, the Government on April 13 issued Presidential Decree No. 12 of 2020 concerning the Determination of the National Disaster for the Spread of Corona Virus Disease 19 (Covid-19) as a National
Disaster. The government then issued Presidential Decree No. 7 of 2020 concerning the Task Force for the Acceleration of Handling of Corona Virus Desease 19 (Covid19). This Presidential Decree has been amended by Presidential Decree No. 9 of 2020 concerning Amendments to Presidential Decree No.7 of 2020 concerning the Task Force for the Acceleration of Handling Corona Virus Disease 2019 (Covid-19).

Responding to the increasing Covid-19 cases in Indonesia, the Ministry of Administrative and Bureaucratic Reform issued a policy in the form of a Ministerial Circular Letter No. PANRB. 19 of 2020 concerning Adjustments to the Work System of the State Civil Apparatus in Efforts to Prevent Covid-19 in Government Agencies. Because it has not improved, the Government has decided to extend the implementation of the policy of the State Civil Apparatus (ASN) to work at home (work from home) until April 21, 2020. The extension of the work from home (WFH) period for ASN is contained in the Circular of the Minister of PANRB No. 34 of 2020 concerning Amendments to the Circular of the Minister of PANRB No. 19 of 2020 concerning Adjustments to the ASN Work System in Efforts to Prevent the Spread of Covid-19 in Government Agencies. There are still many Government ideas to accelerate the handling of Covid-19. However, not all of them can be discussed here. 


\section{Acceptance.}

In the perspective of the Pancasila Element Theory, acceptance is the perception / response to the government's ideas or actions to prevent the spread of Covid-19. The perception in question is a reaction or response of citizens to the Government's efforts to prevent the transmission of Covid-19. This response can come from his knowledge and experience during the Covid-19 pandemic. This knowledge and experience gave birth to a view on Covid-19. This view forms the principles that direct people's attitudes in responding to the Covid-19 phenomenon.

This means that knowledge and experience are two influencing factors in responding to the Covid-19 pandemic. Knowledge relates to the level of education. There will be different responses between those with low and high education. Likewise, there will be different ways to digest and manage the Covid-19 information it receives. For those who are highly educated, of course, before responding to Covid-19, they must first collect information.

Of course, the information that is collected is the official and credible source. This type of person is critical in receiving information. Because it only believes that information comes from government agencies that handle the spread of Covid-19. This is to get more accurate information. So that the response to Covid-19 can be done well.
While the response comes from experience, having experienced it myself, for example being infected with Covid-19. Maybe you have had contact with people who have been exposed to Covid-19, thus shaping and directing them to the right response. For example, because a neighbor or friend is infected with Covid-19.

Based on the increase in the number of Covid-19 cases in Indonesia, a conclusion has come that the public acceptance of the Government's ideas in controlling the spread of Covid-19 is very weak. Citizens are not disciplined in obeying the government's appeal. Not only appeals, any policies issued by the Government in preventing the spread of Covid-19 often get ridicule from residents.

Even during the observations of researchers there are still residents who are indifferent to the Government's efforts to control the spread of Covid-19. They feel smarter than the Government about Covid-19. The massive information circulating in the public, that Covid-19 is part of a global conspiracy, has made many citizens do not believe the truth of Covid-19. If Covid-19 is believed to be a conspiracy, then the efforts made by the Government are not well accepted. In fact, the Government's efforts have turned into gossip and jokes by the citizens. Not a few residents responded to the Government's efforts to contain the spread of Covid-19 with ridicule. 
Agreement.

In the perspective of the Pancasila Element Theory, agreement is the agreement between one or more people and other parties. Likewise, in preventing the spread of Covid19 , there must be an agreement first. Then who is involved in this agreement. The government and its people are the two parties who must agree with their will in viewing Covid-19. Without an agreement between the two parties, it is impossible for Covid-19 to be resolved. It is possible that there will be a misunderstanding between the will of the Government and its citizens. Even the good intentions of the Government to control Covid19 could be misinterpreted by its citizens.

Observing the real conditions on the ground, it seems that there is a mismatch between the Government and its citizens in looking at the Covid-19 problem. The incompatibility of the will of the two parties in turn led to a polemic in controlling Covid-19. If the Government sees Covid-19 as a thorny and threatening problem. So there are still many residents who doubt the truth of Covid19 as a dangerous virus. Citizens disagreement arose, because they doubted whether Covid-19 really existed? How do you recognize other people who have been exposed to Covid-19? There is still a lot of confusion to answer this question. If so, is it possible that there is a common perception between the Government and its citizens regarding Covid-19.
There are still residents who have the prejudice that Covid-19 is a global conspiracy. This perception is what makes some residents doubt the truth of Covid-19. Even more so when you are asked what is Covid-19? To answer this problem, the Government has educated its citizens regarding the characteristics of people exposed to Covid-19. In general, the symptoms of people exposed to Covid-19 are actually usually experienced by residents in their daily lives. Let's just say that residents have agreed to this as a symptom to recognize people exposed to Covid-19.

This then became confused with the discovery of people who were exposed to Covid-19 but did not show symptoms or people without symptoms (OTG). The OTG phenomenon certainly confuses residents with Covid-19. The confusion of residents has led to the understanding that even healthy people suffer from Covid-19. This is what shapes people's perceptions that Covid-19 does not exist. Moreover, many people who died were later diagnosed with Covid-19. It can be seen that various attempts by the Government to get residents' agreements regarding the initial symptoms of people being infected with Covid-19 have failed. The absence of an agreement is what affects the behavior of citizens in responding to Government policies.

Disagreements about Covid-19 at the conceptual level clearly have an effect in handling it. For example, since the emergence of Covid-19, it is known as a virus that is 
transmitted through the air. So to prevent its spread, the Government advises people who experience early symptoms to wear masks. On one occasion, Minister of Health Terawan stated that those who must wear masks are sick people, not healthy people. Not long after, controversy accompanied the Minister of Health's statement. Whether the opinion expressed by the Minister of Health is of course a public polemic. On the way, residents are required to wear masks without exception. This inconsistency of the government certainly confuses its citizens. Following this, residents began to question the consistency of the Government's attitude in handling Covid-19.

The cross-will between the Government and its citizens in preventing Covid-19 did not end there. Due to the ban on crowding issued by the Government, in this case the Police have also received a cold reception from the public. Because people still carry out activities by gathering large numbers of people in one place. The residents also violated the health protocol recommended by the government. Even though this rule is part of the application of physical distancing. Unreached common ground is also evident in the PSBB policy issued by the Government. Many residents disagreed with the Government's policies regarding the enforcement and implementation of the PSBB.

\section{Truth.}

In the perspective of the Pancasila Element Theory, truth is a necessity that refers to and refers to the provisions set by the authorized institution to prevent the spread of Covid-19 from spreading. The truth here includes and includes the implementation of provisions relating to the handling of Covid-19 in Indonesia by the authorities, whether it has been carried out consistently. It is this principle of truth that should most determine the success of the Government's efforts in controlling the spread of Covid-19. Of course, the truth that the Government is trying to uphold originates from the emergence of the Covid-19 problem which is trying to be resolved with critical and logical thinking, so that it can be accepted and agreed upon by the residents.

If the Government's efforts to construct the truth do not go through this process, it is impossible for peace to materialize. The peace in question is that Indonesia is free from Covid-19. Therefore, the truth in handling Covid-19 in Indonesia cannot only be placed and borne by the Government as a policy maker. Citizens as policy targets must also act properly in accordance with the provisions set by the Government in preventing the spread of Covid-19. Without citizen support, it is impossible for the government to realize the truth in controlling the transmission of Covid19.

Looking at the current situation that shows an increase in Covid-19 cases in Indonesia, it can be said that there has been a violation of the principle of truth in dealing 
with the threat of the virus. From the beginning it was predictable that the truth that the Government's construction in handling Covid19 received less acceptance from some residents. How can the truth of handling Covid-19 be realized if there are still residents who do not believe in the virus? Because this perception gave birth to some residents' indifference to Covid-19. This certainly makes the spread of Covid-19 in Indonesia even more fertile. In a situation like this, it is impossible for the government to control the transmission of Covid-19.

The truth in dealing with the spread of Covid 19 in Indonesia is increasingly difficult to realize because the enforcement of Government policies is not matched by the consistency of the implementing apparatus. For example, law enforcement officials hesitate to carry out their duties to take firm action against citizens who violate the Covid19 health protocol policy. Such as the government's appeal regarding psychological distancing. Although it is well known that Covid-19 transmission occurs through physical contact, but activities that accumulate large numbers of people, such as demonstrations, are still tolerated by the authorities. They argue that demonstrations are a human right guaranteed by the 1945 Constitution (Santika, 2019). Is it true that the 1945 Constitution guarantees the human rights of citizens to gather and congregate in the Covid-19 pandemic situation? Of course not.
Given that allowing citizens to gather and crowd in the midst of the Covid-19 pandemic, it is clearly endangering their safety. That way, prohibiting residents from crowding in the midst of the Covid-19 pandemic is the most correct action. Moreover, the safety of citizens is a human right (right to life) which the authorities have to protect. But because they were pressed by mass pressure, it seemed as if the security forces had closed their ears. This inconsistency of the apparatus clearly cannot be justified from the point of view of Pancasila (Ngurah et al, 2019).

The untruth in enforcing regulations related to Covid-19 can be seen from the dualism of the attitudes of law enforcement officials. This can be seen from the handling of crowd cases that violate the Covid-19 health protocol. It is as if law enforcement officers were selective in enforcing the rules related to controlling the spread of Covid-19. Unfair law enforcement against violators of the Covid-19 health protocol has in turn weakened citizens' confidence in the truth of Covid-19. So the actions of law enforcement officials in implementing regulations related to Covid-19 at least have helped shape the perceptions of citizens. In law enforcement, the apparatus should uphold the principle of truth in implementing the Covid-19 health protocol regulations. Anyone who violates the provisions in controlling the spread of Covid19 should be dealt without discrimination. 
Government policy to hold political contestation in the middle (Santika, Purnawijaya, et al., 2019) During the Covid-19 pandemic, it is certainly impossible to be justified from the standpoint of Pancasila. Given the decreasing level of citizen trust in the seriousness of the Government in tackling Covid-19. To make matters worse, the Covid19 problem prior to the implementation of the Regional Elections became a joke for residents. Because the Government at that time said that the number of people infected with Covid-19 in Indonesia had relatively decreased. So that with this condition and the implementation of strict health protocols, the elections can be carried out. Even though the Government's political will to hold regional elections has actually reinforced people's beliefs that Covid-19 is actually a conspiracy.

Especially with the emergence of new findings, that there are hospitals that have Covid patients. On several occasions, state officials conveyed these findings to the public. These improper practices naturally confuse people with Covid-19. Unfortunately, until now the competent authorities have not taken any action to restore people's trust (Santika, 2020).

\section{Peace.}

In the perspective of the Pancasila Element Theory, peace is the feeling that citizens feel when Covid-19 leaves Indonesia. Because before it broke out in Indonesia, Covid-19 actually disturbed the peace of the people. Because sooner or later, Covid-19 will spread throughout the world, including Indonesia. It was proven that in early March 2020 two residents were announced to be exposed to Covid-19. There are many things related to Covid-19 that bring discord. How can residents be peaceful if Covid-19 is still haunting and being a very mysterious figure. Symptoms that are similar to ordinary diseases make it quite difficult for ordinary citizens to distinguish between people who are infected with Covid-19. Concerns are mounting because Covid-19 is a virus whose character is very quickly transmitted and infects the human body.

The lack of peace is increasingly disturbing because the thought of solving the Covid-19 problem does not seem to bear fruit. Because ideas in the form of appeals and regulations have not been obeyed. Meanwhile, the obedience and obedience of citizens as a form of acceptance of Government policies in controlling the spread of Covid-19 is getting lower. It is impossible for Indonesia to be peaceful, if its citizens still disobey Government policies in preventing the spread of Covid-19. The anxiety is getting higher when we see that there is no agreement between the Government and its citizens in looking at the Covid-19 issue. Not to mention, there are many incorrect practices in implementing Government policies to tackle the transmission of Covid-19 in Indonesia. Thus, the handling of Covid-19 in Indonesia 
contains problems, so it is impossible to achieve peace.

\section{CONCLUSION}

By using the Pancasila Element Theory as binoculars in examining the handling of Covid-19 in Indonesia, the researchers concluded that the Government will have difficulty controlling the spread of this virus. Because the fundamental problem in preventing the spread of Covid-19 is that this virus is classified as a mysterious figure. The thinking of the Government through ideas in the form of appeals and regulations seems to have received a cold reception from the citizens. Many residents do not accept and agree with the Government's efforts to control Covid-19. If so, it is impossible for the Government to be able to prevent the spread of Covid-19. Thus, the peace seen from the disappearance of Covid-19 in Indonesia is only wishful thinking that is difficult to realize.

\section{REFERENCES}

[1] Agustino, L. (2020). Analisis Kebijakan Penanganan Wabah Covid-19: Pengalaman Indonesia Analysis Of Covid-19 Outbreak Handling Policy: The Experience Of Indonesia. Junal Borneo Administrator, 16(2), 253-270.

[2] Faisal, F., Hasima, R., \& Oleo, U. H. (2020). Peningkatan Pemahaman Hukum MasyarakatTerhadap Kebijakan Pemerintah dalam Pencegahan COVID-19 Melalui Media Poster di Desa Tombawatu Kecamatan Kapoiala Kabupaten Konawe. 1(4), 291-298.

[3] Lin, C., Chen, Z., Xie, B., Sun, Z., Ding, Y., \& Li, X. (2020). Since January 2020 Elsevier has created a COVID-19 resource centre with free information in English and Mandarin on the novel coronavirus COVID- 19. The COVID-19 resource centre is hosted on Elsevier Connect, the company's public news and information. January.

[4] Liu, Y. C., Kuo, R. L., \& Shih, S. R. (2020). COVID-19: The first documented coronavirus pandemic in history. Biomedical Journal, $\quad 43(4)$, 328-333. https://doi.org/10.1016/j.bj.2020.04.007

[5] Nasruddin, R., \& Haq, I. (2020). Pembatasan Sosial Berskala Besar (PSBB) dan Masyarakat Berpenghasilan Rendah. SALAM: Jurnal Sosial Dan Budaya Syar-I, 7(7). https://doi.org/10.15408/sjsbs.v7i7.15569

[6] Rahmatullah, indra. (2020). Jaminan Hak Kesehatan Pekerja Work From Office. Jurnal Buletin Hukum Dan Keadilan, 4(1), 57-62.

[7] Santika, I. G. N. (2017). Kepala Sekolah Dalam Konsep Kepemimpinan Pendidikan: Suatu Kajian Teoritis. Widya Accarya, 7(1). http://103.39.12.42/index.php/widyaaccarya/ article/view/898

[8] Santika, I. G. N. (2019). Presidensialisme Dan Problematika Mekanisme Impeachment Presiden Dan / Atau Wakil Presiden Berdasarkan UUD 1945 Pasca Perubahan ( Perspektif Pergulatan Hukum Dan Politik ). Jurnal Ilmiah Ilmu Sosial, 5(1), 23-34. http://dx.doi.org/10.23887/jiis.v5i1.18777

[9] Santika, I. G. N. (2020a). Menelisik Akar Kegaduhan Bangsa Indonesia Pasca Disetujuinya Hasil Revisi UU KPK Dalam Perspektif Pancasila. Jurnal Ilmiah Ilmu Sosial, 6(1), 26-36. https://doi.org/10.23887/jiis.v6i1.25001

[10] Santika, I. G. N. (2020b). Optimalisasi Peran Keluarga Dalam Menghadapi Persoalan Covid- 19: Sebuah Kajian Literatur. Jurnal Ilmiah Ilmu Sosial, 6(2), 127-137. https://doi.org/http://dx.doi.org/10.23887/jiis. v6i2.28437

[11] Santika, I. G. N. (2021a). Grand Desain Kebijakan Strategis Pemerintah Dalam Bidang Pendidikan Untuk Menghadapi Revolusi Industri 4.0. Jurnal Education and Development, 9(2), 369-377. 
[12] Santika, I. G. N. (2021b). Pendidikan Kewarganegaraan (Studi Komparatif Konstitusi Dengan UUD 1945). Lakeisha.

[13] Santika, I. G. N., Purnawijaya, I. P. E., \& Sujana, I. G. (2019). Membangun Kualitas Sistem Politik Demokrasi Indonesia Melalui Pemilu Dalam Perspektif Integrasi Bangsa Dengan Berorientasikan Roh Ideologi Pancasila. Seminar Nasional Hukum Dan Kewarganegaraan, $\quad$ 1(1), 74-85. https://eproceeding.undiksha.ac.id/index.php/ semnashk/article/view/1665

[14] Santika, I. G. N., Sujana, G., \& Winaya, M. A. (2019). Membangun Kesadaran Integratif Bangsa Indonesia Melalui Refleksi Perjalanan Historis Pancasila Dalam Perspektif Konflik Ideologis. Journal of Etika Demokrasi (JED), 4(2), 89-98. https://doi.org/https://doi.org/10.26618/jed.v $4 \mathrm{i} 2.2391$

[15] Siahaineinia, H. E., \& Bakara, T. L. (2020). Persepsi Masyarakat Tentang Penggunaan Masker Dan Cuci Tangan Selama Pandemi Covid-19 Di Pasar Sukaramai Medan. Wahana Inovasi: Jurnal Penelitian Dan Pengabdian Masyarakat UISU, 9(1), 173176.

https://jurnal.uisu.ac.id/index.php/wahana/art icle/view/2874

[16] WHO. (2020). Coronavirus disease (COVID2019) situation reports. Geneva: World Health Organization; 2020. Available: www.who.int/emergencies/diseases/novel coronavirus-2019/situation-reports (accessed 2020 June 12). Who, June. 